\title{
Legalitas Perluasan Penggunaan Alat Bukti Elektronik Dalam Penegakan Hukum Pidana Indonesia
}

\section{Legality of the Use of Electronic Evidence in the Enforcement of Indonesian Criminal Law}

\author{
I Made Wirawan \\ Kepolisian Republik Indonesia \\ E-mail:wira32krimsus@gmail.com \\ Oheo K. Haris \\ Pascarjana Universitas Halu Oleo \\ E-mail: oheokh@gmail.com \\ Handrawan \\ Pascarjana Universitas Halu Oleo \\ E-mail: handrawansaranani84@gmail.com
}

\begin{abstract}
The main problem in this study is the legality in question of electronic evidence; and the strength of proof of electronic evidence in court proceedings. To find out the answers to the questions asked, conduct a research consisting of normative juridical with a method that discusses conceptual negotiations and consultations as well as problem discussions. The results showed that with regard to in this case, electronic evidence that proves as valid evidence with its status as independent evidence and evidence that does not have guaranteed authenticity. Its status as an independent evidence is part of the types of evidence specified in the Criminal Procedure Code, namely as a form of proof of payment that meets the functional requirements/functional equivalent (functional equivalent approach) and part of the source of evidence. Electronic evidence can also be used as legal evidence in the Criminal Procedure Code to prove all types of court proceedings in court. Although the Criminal Procedure Code as a general lex is not given, but based on Law No. 11 of 2008 Jo. UU no. 19 of 2016 as a lex specialist, electronic evidence can be used as valid evidence to substantiate court proceedings. Regarding the power of electronic evidence as evidence in the Criminal Procedure Code is still not strong before there is a statement from the experts or experts in electronics and telematics themselves. The legal interpretation of the judge will change the status to electronic by generalizing electronic evidence that changes the status of the electronic evidence.
\end{abstract}

Keyword: Legality; Expansion Of Electronic Evidence; Law Enforcement

Abstrak: Permasalahan pokok dalam penelitian ini adalah legalitas perluasan alat bukti elektronik; dan kekuatan pembuktian alat bukti elektronik dalam persidangan. Untuk mengetahui jawaban dari permasalahan yang diajukan, dilakukan penelitian yang 
berbentuk yuridis normatif dengan metode pendekatan perundang-undangan dan pendekatan konseptual serta pendekatan kasus. Hasil penelitian menunjukkan bahwa berkenaan dengan Dalam hal ini, bukti elektronik diakui sebagai alat bukti yang sah dengan statusnya sebagai alat bukti yang berdiri sendiri dan alat bukti yang tidak sendiri (pengganti surat dan perluasan bukti petunjuk sepanjang berasal dari sistemyang reliabel atau terjaga sistem keamanannya sehingga terjamin keautentikannya). Statusnya sebagai alat bukti yang berdiri sendiri berarti merupakan bagian dari jenis-jenis alat bukti yang ditentukan dalam KUHAP, yaitu sebagai pengganti bukti surat apabila memenuhi prinsip kesetaraan fungsional/padanan fungsional (functional equivalent approach) dan bagian dari bukti petunjuk. Bukti elektronikjuga seharusnya dapat digunakan sebagai alat bukti yang sah dalam KUHAP untuk pembuktian seluruh jenis tindak pidana di pengadilan. Walaupun KUHAP sebagai lex generalist tidak mengaturnya, namun berdasarkan pada Undang-Undang Republik Indonesia Nomor 11 Tahun 2008 tentang Informasi dan Transaksi Elektronik Jo. Undang-Undang Republik Indonesia Nomor 19 Tahun 2016 tentang Perubahan Atas Undang-Undang Republik Indonesia Nomor 11 Tahun 2008 tentang Informasi dan Transaksi Elektronik sebagai lex specialist, bukti elektronik dapat digunakan sebagai alat bukti yang sah untuk pembuktian seluruh tindak pidana di pengadilan. Mengenai kekuatan hukum alat bukti elektronik sebagai alat bukti pada khususnya dalam KUHAP masih belum kuat sebelum adanya keterangan dari pihak yang ahli atau pakar elektronik dan telematika sendiri. Interpretasi hukum hakim akan mengubah status bukti elektronik dengan melakukan generalisasi bukti elektronik yaitu mengubah status bukti elektronik tersebut.

Kata kunci: Legalitas; Perluasan Bukti Elektronik; Penegakan Hukum

\section{PENDAHULUAN}

Undang-Undang Republik Indonesia Nomor 19 Tahun 2016 tentang Perubahan Atas UndangUndang Republik Indonesia Nomor 11 Tahun 2008 tentang Informasi dan Transaksi Elektronik menegaskan tentang penggunaan bukti elektronik (evidence electronic) dalam melakukan penegakan hukum terkait kegiatan masyarakat yang komunikasinya mengandung unsur perbuatan melawan hukum dengan kemanfaatan internet di ruang maya (cyber space). ${ }^{1}$

Perluasan penggunaan alat bukti elektronik di dalam proses peradilan terhadap perbuatan pidana terkait atas penggunaan kemanfaatan teknologi diperlukan, selaras dengan perubahan perilaku sosial kehidupan masyarakat yang berada dalam kemanfaatan media (convergance media). Hal ini menjadi perubahan kebijakan hukum yang sangat penting dan diperlukan bagi penegakan hukum terhadap ketentuan unsur perbuatan melawan hukum di ruang sunyi dunia maya. ${ }^{2}$

Sistem pembuktian di era teknologi informasi sekarang ini nyatanya menghadapi tantangan besar yang memerlukan penanganan serius, khususnya dalam kaitan dengan upaya

1 Undang-Undang Republik Indonesia Nomor 11 Tahun 2008 tentang Teknologi dan Informasi Elektronik

2 Sri Ayu Astuti, "Perluasan Penggunaan Bukti Elektronik(Evidence of Electronic) Terkait Ketentuan Alat Bukti Sah atas Perbuatan Pidana di Ruang Mayantara (Cyberspace)”, Pagaruyuang Law Journal, Volume 1 Nomor 1, Juli 2017, hlm. 44-57. 
pemberantasan kejahatan di dunia maya (cybercrime). Hal ini muncul karena bagi sebagian pihak jenis-jenis alat bukti yang selama ini dipakai untuk menjerat pelaku tindak pidana tidak mampu lagi dipergunakan dalam menjerat pelaku-pelaku kejahatan di dunia maya (cybercrime). ${ }^{3}$

Kehadiran bukti elektronik di kehidupan penegakan hukum pidana telah menimbulkan kontroversi. Pengaturan bukti elektronik tidak terdapat di dalam Kitab Undang-Undang Hukum Acara Pidana, namun hanya diatur dalam undang-undang yang bersifat khusus. Berkaitan dengan bukti elektronik ada pihak yang mempertanyakan statusnya ketika digunakan untuk pembuktian tindak pidana umum di pengadilan. ${ }^{4}$

Sementara itu pesatnya teknologi informasi melalui internet telah mengubah aktivitasaktivitas kehidupan yang semula perlu dilakukan secara kontak fisik, kini dengan menggunakan media cyberspace, aktivitas keseharian dapat dilakukan secara virtual atau maya. Masalah pelik yang dihadapi penegak hukum saat ini adalah bagaimana menjaring pelaku cybercrime yang mengusik rasa keadilan tersebut dikaitkan dengan ketentuan pidana yang berlaku.

Sebelum adanya putusan Mahkamah Konstitusi tersebut, telah terdapat pertanyaan hukum mengenai kedudukan dari informasi elektronik dan dokumen elektronik dalam kitab undang-undang hukum acara pidana di Indonesia. Jika kita menganalisis ketentuan Pasal 5 ayat (2) UU ITE, di situ dikatakan bahwa keduanya merupakan perluasan dari alat bukti yang sah sesuai dengan hukum acara yang berlaku. Tidak ada penjelasan yang sah mengenai apa yang dimaksud dengan perluasan tersebut sehingga timbul pertanyaan apakah perluasan tersebut dimaknai sebagai penambahan alat bukti atau merupakan bagian dari alat bukti yang telah ada. Dalam Pasal 184 Undang-Undang Republik Indonesia Nomor 8 Tahun 1981 tentang Kitab Undang-Undang Hukum Acara Pidana (KUHAP) terdapat lima alat bukti yaitu keterangan saksi, keterangan ahli, surat, petunjuk dan keterangan terdakwa dan jika perluasan tersebut dimaknai penambahan maka alat bukti dalam kitab undang-undang hukum acara pidana di Indonesia secara umum menjadi lebih dari lima. Pertanyaan selanjutnya adalah apakah informasi elektronik dan data elektronik tersebut dapat dijadikan dasar sebagai alat bukti petunjuk bagi Majelis Hakim. Kemudian apabila perluasan tersebut dimaknai sebagai bagian dari alat bukti yang telah ada maka alat bukti dalam hukum pidana secara umum tetap lima, namun baik

\footnotetext{
3 Dikdik M. Arief Mansur, Elisatris Gultom, Cyber Law Aspek Hukum Tekonologi Informasi, Bandung: Refika Aditama, 2005, hlm. 97.

4 Ramiyanto, “Bukti Elektronik Sebagai Alat Bukti Yang Sah Dalam Hukum Acara Pidana”, Jurnal Hukum dan Peradilan, Volume 6 Nomor 3, November 2017, hlm. 463-486.
} 
informasi elektronik dan dokumen elektronik tersebut dapat dimasukkan dalam alat bukti petunjuk atau alat bukti surat. ${ }^{5}$

\section{ANALISIS DAN PEMBAHASAN}

\section{Keabsahan Alat Bukti Elektronik Dalam Hukum Acara Pidana}

Menurut Yahya Harahap' Pasal 184 ayat (1) KUHAP telah menentukan secara "limitatif" alat bukti yang sah menurut undang-undang. Di luar alat bukti itu, tidak dibenarkan dipergunakan untuk membuktikan kesalahan terdakwa. Ketua sidang, penuntut umum, terdakwa atau penasihat hukum, terikat dan terbatas hanya diperbolehkan mempergunakan alat-alat bukti itu saja. Mereka tidak leluasa mempergunakan alat bukti yang dikehendakinya di luar alat bukti yang ditentukan Pasal 184 ayat (1) KUHAP. Yang dinilai sebagai alat bukti, dan yang dibenarkan mempunyai "kekuatan pembuktian" hanya terbatas kepada alat-alat bukti itu saja. Pembuktian dengan alat bukti di luar jenis alat bukti itu, tidak mempunyai nilai serta tidak mempunyai kekuatan pembuktian yang mengikat.

Mengenai keabsahan alat bukti elektronik menurut hukum atas dasar Pasal 5 ayat (1), ayat (2) dan Pasal 44 huruf b UU ITE sebagaimana yang telah diubah oleh Undang-Undang Republik Indonesia Nomor 19 Tahun 2016 tentang Perubahan Atas Undang-Undang Republik Indonesia Nomor 11 Tahun 2008 tentang Informasi dan Transaksi Elektronik, informasi elektronik dan/atau dokumen elektronik dan/atau hasil cetakannya merupakan perluasan dari alat bukti hukum yang sah sesuai dengan hukum acara yang berlaku di Indonesia. Karena dalam pertanyaan yang Anda tunjukkan untuk hukum acara pidana, maka perluasan yang dimaksud adalah Pasal 184 ayat (1) KUHAP.

Diakuinya informasi dan/atau dokumen elektronik sebagai alat bukti elektronik karena keberadaan informasi elektronik dan/atau dokumen elektronik mengikat dan diakui sebagai alat bukti yang sah untuk memberikan kepastian hukum terhadap penyelenggaraan sistem elektronik dan transaksi elektronik, terutama dalam pembuktian dan hal yang berkaitan dengan perbuatan hukum yang dilakukan melalui sistem elektronik. ${ }^{7}$

5 Vidya Prahassacitta, CCTV Sebagai Alat Bukti Pidana Pasca Putusan MK 20/PUU-XIV/2016, Binus University, https://business-law.binus.ac.id/2016/11/22/kedudukan-cctv-sebagai-alat-bukti-hukum-pidana-pasca-putusanmk-2016/, diakses pada tanggal 23 Februari 2020.

6 M. Yahya Harahap. Pembahasan Permasalahan dan Penerapan KUHAP: Pemeriksaan Sidang pengadilan, Banding, Kasasi dan Peninjauan Kembali. Jakarta: Sinar Grafika, 2010, hlm. 285.

7 Penjelasan Pasal 5 ayat (1) Undang-Undang Republik Indonesia Nomor 19 Tahun 2016 tentang Perubahan Atas Undang-Undang Republik Indonesia Nomor 11 Tahun 2008 tentang Informasi dan Transaksi Elektronik 
Tetapi perlu diperhatikan bahwa berdasarkan Putusan Mahkamah Konstitusi Nomor 20/PUU-XIV/2016 dijelaskan sebagai berikut:

"Frasa "Informasi Elektronik dan/atau Dokumen Elektronik" dalam Pasal 5 ayat (1) dan ayat (2) serta Pasal 44 huruf b UU ITE bertentangan dengan UUD 1945 dan tidak mempunyai kekuatan hukum mengikat sepanjang tidak dimaknai khususnya frasa "Informasi Elektronik dan/atau Dokumen Elektronik" sebagai alat bukti dilakukan dalam rangka penegakan hukum atas permintaan kepolisian, kejaksaan, dan/atau institusi penegak hukum lainnya yang ditetapkan berdasarkan undang-undang sebagaimana ditentukan dalam Pasal 31 ayat (3) Undang-Undang Republik Indonesia Nomor 11 Tahun 2008 tentang Informasi dan Transaksi Elektronik".

Komisaris Besar Polisi Muhammad Nuh Al-Azhar berpendapat bahwa, pada praktiknya penegak hukum (hakim dan jaksa) terbagi dua pendapat mengenai alat bukti elektronik. Ada yang memosisikan informasi dan/atau dokumen elektronik sebagai alat bukti keenam, ada yang menjadikan alat bukti elektronik sebagai perluasan dari alat bukti di Pasal 184 ayat (1) KUHAP. Menurutnya kedua pendapat itu benar, yang terpenting adalah alat bukti itu di dapat secara sah. Ia pula menambahkan, bahwa seorang ahli digital forensic akan menentukan keabsahan suatu alat bukti elektronik di persidangan. Berangkat dari prinsip bahwa every evidence can talk, yang dapat membuat alat bukti elektronik "berbicara" adalah seorang ahli digital forensic. Penjelasan ahli tersebut nantinya akan dilakukan dengan cara merekonstruksi alat bukti elektronik, sehingga membuat terang jalannya persidangan.

Seiring berjalannya waktu, perkembangan alat bukti pada acara pidana seperti yang dijelaskan oleh Komisaris Besar Polisi Muhammad Nuh Al-Azhar di atas. Alat bukti elektronik secara sah diakui untuk pembuktian di persidangan. Yang terpenting adalah bagaimana alat bukti itu didapatkan, tentunya harus sesuai hukum yang berlaku. Selain itu, tidak sembarang orang yang dapat menjelaskan mengenai alat bukti elektronik, untuk itu eksistensi digital forensic dibutuhkan dalam penanganan perkara pidana terkait pembuktian dengan alat bukti elektronik. ${ }^{8}$

\section{Penggunaan Bukti Elektronik sebagai Alat Bukti Di Pengadilan}

Bukti elektronik berstatus sebagai alat bukti yang berdiri sendiri dan alat bukti yang tidak berdiri sendiri (pengganti surat dan perluasan bukti petunjuk). Bukti elektronik tidak diatur dalam KUHAP, tetapi diakui dalam praktik peradilan pidana dan terdapat pengaturannya dalam

8 Dimas Hutomo, Keabsahan Alat Bukti Elektronik dalam Hukum Acara Pidana, Hukum Online https://www.hukumonline.com/klinik/detail/ulasan/lt5c4ac8398c012/keabsahan-alat-bukti-elektronik-dalamhukum-acara-pidana/\#_ftn2, diakses pada tanggal 15 Agustus 2019. 
beberapa undang-undang khusus serta instrumen hukum yang dikeluarkan oleh Mahkamah Agung. Di dalam undang-undang khusus telah ditentukan, bahwa bukti elektronik dapat digunakan untuk pembuktian perkara pidana, baik di tingkat penyidikan, penuntutan maupun pengadilan. 9

Menurut Sigid Suseno, alat bukti yang dikumpulkan oleh penyidik harus dapat diterima oleh pengadilan. Dalam konteks kerja sama internasional persyaratan dapat diterimanya suatu alat bukti digital (informasi dan dokumen elektronik) harus diperhatikan oleh pembentuk peraturan perundang-undangan dan aparat penegak hukum suatu negara. Apabila diperlukan, maka peraturan mengenai cara bagaimana alat bukti digital diperoleh dan dikumpulkan harus dibentuk. Di Amerika Serikat misalnya alat bukti dapat diterima oleh pengadilan bila diperoleh secara sah, yaitu alat bukti harus diperoleh berdasarkan hukum yang mengatur mengenai penggeledahan dan penyitaan. ${ }^{10}$ Jadi, alat bukti yang memenuhi syarat yang dikumpulkan oleh penyidik (termasuk bukti elektronik) tidak boleh ditolak oleh pengadilan.

Debra L. Shinder mengemukakan, bahwa terdapat beberapa syarat yang harus dipenuhi agar alat bukti dapat diterima di pengadilan, yaitu pertama, alat bukti harus kompeten (reliable dan credible) sehingga terjamin validitasnya. Melalui sistem keamanan informasi yang certified, maka integritas konten dalam suatu bukti elektronik (informasi dan/atau dokumen elektronik) menjadi terjamin keautentikannya ${ }^{11}$; kedua, alat bukti harus relevan (dapat membuktikan fakta dari suatu kasus); dan ketiga, alat bukti harus material (memperkuat persoalan yang dipertanyakan dalam suatu kasus). Syarat-syarat yang dikemukakan oleh Debra itu merupakan syarat sahnya suatu bukti elektronik. Hukum positif yang mengatur mengenai keabsahan bukti elektronik dapat dilihat dalam Undang-Undang Republik Indonesia Nomor 11 Tahun 2008 tentang Informasi dan Transaksi Elektronik yang telah diubah dengan Undang-Undang Republik Indonesia Nomor 19 Tahun 2016.

9 Daus Harizona, Kekuatan Bukti Elektronik Sebagai Bukti di Pengadilan Menurut Hukum Acara Pidana dan Hukum Islam (Penggunaan rekaman Gambar Closed Circuit Television), Jurnal Intelektualita: Keislaman, Sosial dan Sains, Vol. 7, No. 1, Jul. 2018, hlm. 81-98.

10 Sigid Suseno, Yurisdiksi Tindak Pidana Siber, Bandung: Refika Aditama, 2012, hlm. 227

11 Menurut Edmon Makarim, meskipun suatu informasi atau dokumen elektronik mempunyai kerentanan keamanan terhadap adanya perubahan, namun melalui sistem keamanan informasi dan komunikasi maka keauntetikannya harus melalui proses e-identification and e-authentication system ((e-IDAS) yang mencakup layanan penjelanggaraan jasa sertifikasi (trust services provider) berdasarkan kualifikasi tertentu (quality assurance level) untuk memperjelas aspek kepercayaan terhadap keberadaan sistem pengamanan itu sendiri (electronic signature, electronic seal, electronic time-stamping, electronic registered delivery services, dan web-site authentication). Lihat Edmon Makarim, "Keautentikan Dokumen Publik Elektronik Dalam Administrasi Pemerintahan Dan Pemerintahan Publik," Jurnal Hukum dan Pembangunan, No. 4, 2015, hlm. 518. Sesuai dengan UU ITE, syarat-syarat adanya transaksi elektronik dan/atau dokumen elektronik adalah baik subyek dan sistemnya sudah harus bersertifikasi. 
Pembentukan Undang-Undang Republik Indonesia Nomor 19 Tahun 2016 tentang Perubahan Atas Undang-Undang Republik Indonesia Nomor 11 Tahun 2008 tentang Informasi dan Transaksi Elektronik sebenarnya berkaitan dengan Putusan Mahkamah Konstitusi RI nomor 20/PUU-XVI/2016. Putusan itu merupakan hasil pemeriksaan uji materi (judicial review) yang diajukan oleh Setya Novanto melalui kuasa hukumnya terkait ketentuan bukti elektronik (informasi dan/atau dokumen elektronik) berupa hasil penyadapan (intersepsi) dalam Pasal 5 ayat (1) dan ayat (2) dan Pasal 44 huruf b Undang-Undang Republik Indonesia Nomor 11 Tahun 2008 tentang Informasi dan Transaksi Elektronik serta Pasal 26A UndangUndang Republik Indonesia Nomor 20 Tahun 2001 Jo. Undang-Undang Republik Indonesia Nomor 31 Tahun 1999. Di dalam putusannya tersebut, Mahkamah menyatakan bahwa bukti elektronik (informasi dan/atau dokumen elektronik) termasuk hasil penyadapan (intersepsi) dapat dijadikan sebagai alat bukti yang sah, apabila diperoleh secara sah yang dilakukan dalam rangka penegakan hukum atas permintaan kepolisian, kejaksaan, dan/atau institusi penegak hukum lainnya yang ditetapkan berdasarkan undang-undang. Apabila bukti elektronik tidak diperoleh secara sah, maka hakim mengesampingkan atau menganggap tidak mempunyai nilai pembuktian di pengadilan.

Pasal 5 ayat (3) Undang-Undang Republik Indonesia Nomor 11 Tahun 2008 tentang Informasi dan Transaksi Elektronik menentukan, bahwa informasi elektronik dan/atau dokumen elektronik dinyatakan sah apabila menggunakan sistem elektronik sesuai dengan ketentuan yang diatur dalam undang-undang ini. Kemudian ayat (4) pasal itu menentukan, bahwa ketentuan mengenai informasi dan/atau dokumen elektronik sebagaimana dimaksud pada ayat (1) tidak berlaku untuk: a) surat yang menurut undang-undang harus dibuat dalam bentuk tertulis; dan b) surat beserta dokumennya yang menurut undang-undang harus dibuat dalam bentuk akta notaris atau akta yang dibuat oleh pejabat pembuat akta.

Menurut Pasal 6 Undang-Undang Republik Indonesia Nomor 11 Tahun 2008 tentang Informasi dan Transaksi Elektronik, dalam hal terdapat ketentuan lain selain yang diatur Pasal 5 ayat (4) yang mensyaratkan bahwa suatu informasi harus berbentuk tertulis atau asli, informasi elektronik dan/atau dokumen elektronik dianggap sah sepanjang informasi yang tercantum di dalamnya dapat diakses, ditampilkan, dijamin keutuhannya, dan dapat dipertanggungjawabkan sehingga menerangkan suatu keadaan. Merujuk pada prinsip 
kesetaraan fungsional atau padanan fungsional (functional equivalent approach) ${ }^{12}$, maka informasi dan/atau dokumen elektronik disamakan dengan bukti tulisan atau surat.

Edmon Makarim mengemukakan bahwa persamaan secara fungsional (functional equivalent approach) antara informasi atau dokumen elektronik dengan bukti tulisan apabila memenuhi setidaknya 3 (tiga) dasar, yaitu: ${ }^{13}$

1. Informasi tersebut dianggap 'tertulis' jika ia dapat disimpan dan ditemukan kembali;

2. Informasi tersebut dianggal 'asli' jika yang disimpan dan ditemukan serta dibaca kembali tidak berubah substansinya, atau terjamin keautentikan dan integritasnya; dan

3. Informasi tersebut dianggap "bertanda tangan" apabila terdapat informasi yang menjelaskan adanya suatu objek hukum yang bertanggung jawab di atasnya atau terdapat sistem autentikasi yang reliable yang menjelaskan identitas dan otoritas atau verifikasi dari pihak tersebut.

Dengan demikian, maka bukti elektronik (informasi dan/atau dokumen elektronik) dapat disamakan dengan bukti tulisan apabila memenuhi setidaknya 3 (tiga) prinsip/dasar dalam functional equivalent approach. Hal itu selaras dengan penjelasan Pasal 6 Undang-Undang Republik Indonesia Nomor 11 Tahun 2011, bahwa selama ini bentuk tertulis identik dengan informasi dan/atau dokumen semata, padahal pada hakikatnya informasi dan/atau dokumen dapat dituangkan ke dalam media apa saja, termasuk media elektronik. Dalam lingkup sistem elektronik, informasi yang asli dengan salinannya tidak relevan lagi untuk dibedakan sebab sistem elektronik pada dasarnya beroperasi dengan cara penggandaan yang mengakibatkan informasi yang asli tidak dapat dibedakan lagi dari salinannya. Merujuk pada Pasal 5 ayat (3) dan ayat (4) Jo. Pasal 6 Undang-Undang Republik Indonesia Nomor 11 Tahun 2008 tentang Informasi dan Transaksi Elektronik beserta penjelasannya, maka bukti elektronik dinyatakan sah apabila menggunakan sistem elektronik yang telah ditentukan, serta dianggap sah sebagai alat bukti untuk pembuktian tindak pidana sepanjang yang tercantum di dalamnya dapat diakses, ditampilkan, dijamin keutuhannya, dan dapat dipertanggungjawabkan. Apabila

12 Functional equivalent atau padanan fungsional merupakan salah satu prosedur yang digunakan dalam penerjemahan istilah ilmiah. Contoh kata telemarketing diterjemahkan menjadi pemasaran melalui telepon. Di sini penerjemah memadukan kata tele dengan marketing yang dikonotasikan dengan fungsi dari telepon. Lihat Aris Wuryantoro. Peranan Penerjemahan Istilah dalam Bahasa Indonesia. Makalah disampaikan dalam Prosiding Seminar Nasional PESAT 2005 di Auditorium Universitas Gunadarma, Jakarta, 23-24 Agustus 2005. hlm. 27.

13 Edmon Makarim, "Keautentikan Dokumen Publik Elektronik Dalam Administrasi Pemerintahan dan Pemerintahan Publik." hlm. 532. 
dihubungkan dengan pendapat Debra di atas, maka bukti elektronik yang telah memenuhi syarat reliable, credible, relevan, dan bersifat material, harus diterima oleh pengadilan sebagai alat bukti yang sah dalam hukum acara pidana untuk pembuktian tindak pidana di pengadilan.

Keberadaan informasi dan/atau dokumen elektronik mengikat dan diakui sebagai alat bukti yang sah untuk memberikan kepastian hukum terhadap pelanggaran sistem elektronik dan transaksi elektronik, terutama dalam pembuktian dengan hal yang berkaitan dengan perbuatan hukum yang dilakukan melalui sistem elektronik. Kemudian khusus untuk informasi elektronik dan/atau dokumen elektronik berupa hasil intersepsi atau penyadapan atau perekaman yang merupakan bagian dari penyadapan harus dilakukan dalam rangka penegakan hukum atas permintaan kepolisian, kejaksaan, dan/atau institusi lainnya yang kewenangannya ditetapkan berdasarkan undang-undang.

Dengan demikian dapatlah dipahami, bahwa sifat mengikat dan pengakuan bukti elektronik sebagai alat bukti yang sah adalah untuk memberikan kepastian hukum terhadap pelanggaran sistem elektronik dan transaksi elektronik, terutama untuk pembuktiannya. Kepastian hukum dimaksudkan agar penggunaan bukti elektronik untuk pembuktian perkara pelanggaran sistem elektronik dan transaksi elektronik memiliki dasar hukum yang kuat. Berkaitan dengan hasil intersepsi atau penyadapan atau perekaman, baru dapat digunakan sebagai alat bukti yang sah apabila diminta oleh kepolisian, kejaksaan, dan/atau institusi lainnya dalam rangka penegakan hukum. ${ }^{14}$

\section{KESIMPULAN}

Status bukti elektronik dalam hukum acara pidana dapat di lihat dalam beberapa undangundang khusus dan instrumen hukum yang dikeluarkan oleh Mahkamah Agung (Surat No. 39/TU/88/102/Pid). Dalam hal ini, bukti elektronik sebagai alat bukti yang sah dengan statusnya sebagai alat bukti yang berdiri sendiri dan alat bukti yang tidak sendiri (pengganti surat dan perluasan bukti petunjuk sepanjang berasal dari sistem yang reliable atau terjaga sistem keamanannya sehingga terjamin keautentikannya). Statusnya sebagai alat bukti yang berdiri sendiri berarti merupakan bagian dari jenis-jenis alat bukti yang ditentukan dalam KUHAP, yaitu sebagai pengganti bukti surat apabila memenuhi prinsip kesetaraan fungsional/padanan fungsional (functional equivalent approach) dan bagian dari bukti petunjuk. Bukti elektronik juga seharusnya dapat digunakan sebagai alat bukti yang sah dalam KUHAP

14 Ramiyanto, Op.,Cit. hlm. 14. 
untuk pembuktian seluruh jenis tindak pidana di pengadilan. Walaupun KUHAP sebagai lex generalist tidak mengaturnya, namun berdasarkan pada Undang-Undang Republik Indonesia Nomor 11 Tahun 2008 tentang Informasi dan Transaksi Elektronik Jo. Undang-Undang Republik Indonesia Nomor 19 Tahun 2016 tentang Perubahan Atas Undang-Undang Republik Indonesia Nomor 11 Tahun 2008 tentang Informasi dan Transaksi Elektronik sebagai lex specialist, bukti elektronik dapat digunakan sebagai alat bukti yang sah untuk pembuktian seluruh tindak pidana di pengadilan.

\section{Daftar Pustaka}

\section{Buku}

Harahap, M. Yahya. Pembahasan Permasalahan dan Penerapan KUHAP: Pemeriksaan Sidang Pengadilan, Banding, Kasasi dan Peninjauan Kembali. Jakarta: Sinar Grafika, 2010.

Mansur, Dikdik M. Arief, Elisatris Gultom, Cyber Law Aspek Hukum Tekonologi Informasi, Bandung: Refika Aditama, 2005.

Suseno, Sigid, Yurisdiksi Tindak Pidana Siber, Bandung: Refika Aditama, 2012.

\section{Jurnal/Makalah}

Astuti, Sri Ayu, “Perluasan Penggunaan Bukti Elektronik(Evidence of Electronic) Terkait Ketentuan Alat Bukti Sah atas Perbuatan Pidana di Ruang Mayantara (Cyberspace)", Pagaruyuang Law Journal, Volume 1 Nomor 1, Juli 2017.

Harizona, Daus, Kekuatan Bukti Elektronik Sebagai Bukti di Pengadilan Menurut Hukum Acara Pidana dan Hukum Islam (Penggunaan rekaman Gambar Closed Circuit Television), Jurnal Intelektualita: Keislaman, Sosial dan Sains, Vol. 7, No. 1, Jul. 2018.

Makarim, Edmon, "Keautentikan Dokumen Publik Elektronik Dalam Administrasi Pemerintahan Dan Pemerintahan Publik," Jurnal Hukum dan Pembangunan, No. 4, 2015.

Ramiyanto, "Bukti Elektronik Sebagai Alat Bukti Yang Sah Dalam Hukum Acara Pidana”, Jurnal Hukum dan Peradilan, Volume 6 Nomor 3, November 2017.

Wuryantoro, Aris. Peranan Penerjemahan Istilah dalam Bahasa Indonesia. Makalah disampaikan dalam Prosiding Seminar Nasional PESAT 2005 di Auditorium Universitas Gunadarma, Jakarta, 23-24 Agustus 2005. 


\section{Peraturan Perundang-undangan}

Undang-Undang Republik Indonesia Nomor 8 Tahun 1981 tentang Kitab Undang-Undang Hukum Acara Pidana.

Undang-Undang Republik Indonesia Nomor 11 Tahun 2008 tentang Informasi dan Transaksi Elektronik.

Undang-Undang Republik Indonesia Nomor 19 Tahun 2016 tentang Perubahan Atas UndangUndang Republik Indonesia Nomor 11 Tahun 2008 tentang Informasi dan Transaksi Elektronik.

\section{Situs Web}

Hutomo, Dimas, Keabsahan Alat Bukti Elektronik dalam Hukum Acara Pidana, Hukum Online https://www.hukumonline.com/klinik/detail/ulasan/lt5c4ac8398c012/keabsahanalat-bukti-elektronik-dalam-hukum-acara-pidana/\#_ftn2, diakses pada tanggal 15 Agustus 2019.

Prahassacitta, Vidya, CCTV Sebagai Alat Bukti Pidana Pasca Putusan MK 20/PUU-XIV/2016, Binus University, https://business-law.binus.ac.id/2016/11/22/kedudukan-cctv-sebagai-alatbukti-hukum-pidana-pasca-putusan-mk-2016/, diakses pada tanggal 23 Februari 2020. 